\title{
The Response of the Johannesburg Stock Exchange to Changes in Exchange Rate Regimes
}

\author{
Paul-Francois Muzindutsi \\ School of Economics Sciences \\ North-West University, Republic of South Africa \\ 24754293@nwu.ac.za
}

\section{Doi:10.5901/mjss.2013.v4n6p413}

\begin{abstract}
This paper used Granger Causality test and descriptive statistics analysis to examine the response of the South African stock market to different exchange rate regimes from 1978 to 2008. The analysis of the history of the exchange rate regimes in South Africa showed that the flexibility was introduced in 1979 but the exchange rate shocks of great magnitude appeared during the period of the free-floating exchange rate system (1995-2008). Results reported in this paper revealed that the response of Johannesburg Stock Exchange to changes in the exchange rate was not consistent throughout different exchange rate regimes. A significant correlation between the variables during the sub-periods characterised by capital controls was observed. Granger causality test revealed that the direction of causality changed with exchange rate regimes. This paper concluded that changes in exchange rate regimes have a significant impact on the relationship between the stock market index and the exchange rate.
\end{abstract}

Keywords: Exchange rate regimes, Johannesburg Stock Exchange, Granger causality, unit root test.

\section{Introduction}

This integrated global economy has increased the involvement of firms, both large and small, in international trade and investment. The involvement of companies in cross-border trade and investment requires the conversion of the money from the firm's domestic currency into foreign currency and vice versa. This means that economic and financial instabilities that affect companies may have an impact on the stability of the exchange rate market. The stability of the exchange rate may also be affected by changes in exchange rate regimes (Reinhart, 2000) as some of the exchange rate regimes may increase the volatility of the value of the currency. For example, developing countries that adopt the pegged exchange rate regimes were highly affected by the 1998 financial crisis (Fischer, 2001). A country with flexible exchange rate regimes, such as South Africa, was affected by the September 11, 2001 incident and the 2008 economic crisis in Zimbabwe. Since changes in exchange rate regimes have an impact on the exchange rate volatility and the exchange rate volatility affects the stock market, changes in foreign exchange rate regimes may also affect the stock market. Thus the effect of the international crisis on a country may depend on the exchange rate regime adopted by such country.

Economic theories show that foreign exchange market interacts with the stock market index, but there is no general consensus on how these two markets interact (Granger, Huang \& Yang, 2000; Benson \& Faff, 2003). Previous studies have established that the relationship between the exchange rate and the stock market varies with the nature of the economy and the intervention of the government in the foreign exchange rate market (Ajayi et al.,1998; Abdalla \& Murinde, 1997; Granger et al., 2000). However, the effect of changes in exchange rate regimes on the stock market index has not been established. This paper will therefore establish the response of the Johannesburg Stock Exchange (JSE) to different exchange rate regimes. The rest of the paper is organised as follows. Section 2 provides an overview South African exchange rate regimes; Section 3 discusses the methodology. Section 4 discusses the findings and Section 5 provides the conclusion and recommendations.

\section{Overview of South African Exchange Rate Regimes}

Foreign exchange rate regimes may summarised into two broad categories: basically fixed exchange rate regimes, which 
include fixed and pegged exchange rates, and basically flexible exchange rate regimes, which include managed floating and free floating exchange rates (Tembo, 1999). A free floating exchange is identified by the market forces without the intervention of the central bank while a fixed exchange rate is determined by the central bank through actions of buying and selling of the domestic currency in the foreign exchange market. A managed floating exchange rate, called "crawling peg", is a fluctuating exchange rate with intervention of the central bank to maintain a moderate fluctuation (Madura, 2003). In a pegged exchange rate regime the value of a domestic currency is linked (pegged) to another currency, or to some valuable commodity such as gold (Klein \& Shambaugh, 2008).

Since the 1960s, the South African exchange rate (rand) has been affected by the adoption of different exchange rate regimes. Exchange rate regimes, implemented by the South African Reserve Bank (SARB), changed from a highly controlled exchange rate system to a more liberal exchange rate system (South African Reserve Bank, 2010). In 1961, the South African government took the measure of using the blocked rand system to impose strict controls on capital transfers from the country (Schaling, 2009). This was a policy responding to debt crisis situations in order to protect foreign reserves. The blocked rand system was introduced to restrict the repatriation of funds previously invested in South Africa by foreigners, as well as prohibiting South Africans from transferring funds to foreign countries. Foreign investors could sell local securities on the JSE, but the proceeds from such sales were deposited into blocked rand accounts at commercial banks. Such funds deposited at the bank in the name of foreign investors were named blocked rands. This system interrupted the demand for foreign currency and the supply of rands in the currency market, while it protected the rand from selling pressures that would have emerged from the selling of South African assets by foreign investors (Schaling, 2009).

In the early 1970s, several currencies started to float and this floating of currencies forced several countries to find a replacement for the fixed exchange rate system (Van der Merwe, 2003). The SARB adjusted the exchange rate regime by adopting a new policy of pegging the rand either to the U.S. dollar or to the British pound (Takaendesa, 2006). In August 1971, the Rand was pegged to the United States dollar, because most of the country's foreign transactions were denominated in the U.S dollar (Van der Merwe, 2003). Four months later, during December 1971, the rand was pegged to the British Pound. In June 1972 the British pound started to depreciate against other major currencies, but the rand continued to be linked to the British pound in order to sustain a recovery in the South African balance of payments account (Van der Merwe, 2003). This depreciation of the British pound did not go well with South African economic goals and, as a result, the rand was again pegged to the U.S. dollar in October 1972 and continued to be pegged to the U.S. dollar throughout the year of 1973.

The 1974 oil crisis led to a slowdown in global economic activities and, as a result, the SARB announced the independent managed floating exchange rate system on 21 June 1974 (SARB, 2010). This independent managed floating exchange rate system involved frequent adjustment of the exchange rate, with devaluation every few weeks, until June 1975, when the Authority announced that the rand would be held constant for long periods and only be changed when deemed necessary (Van der Merwe, 2003). This process allowed the rand to be pegged to the U.S. dollar for a long period, with few adjustments. However, a major adjustment was made in September 1975, when the rand was devaluated by $17.9 \%$ because of the decline in the balance of payments (Takaendesa, 2006). Although the rand was pegged to the U.S. dollar for a long period (1972-1979), the securities rand was introduced in February 1976 (Tembo, 1999). From 1976 the South African exchange rate system was characterised by a "variable rand-dollar peg", combined with the securities rand, with a high level of control in capital outflows (Schaling, 2009). This system continued until the beginning of 1979.

In January 1979 an interim report of the De Kock Commission of Inquiry (Commission appointed in 1977 to look into the monetary system and monetary policy in South Africa, focusing primarily on the exchange rate system) concluded that the policy of pegging the rand to the U. S. dollar for long periods had not been conducive to the achievement of targeted economic objectives (Van der Merwe, 2003). To attend to the shortfall of the pegged exchange rate regime, the independent managed floating exchange rate was reintroduced in January 1979 (South African Reserve Bank, 2010). This regime involved a dual-currency exchange rate system, with a commercial rand and a financial rand. The commercial exchange rate was determined daily, based on market factors, while the financial exchange rate was a free-floating rate applicable to foreign exchange transactions made by non-resident portfolio investors (Aron \& Muellbauer, 2001).

In 1983, the dual exchange rate system ended because of the abolishment of the financial rand in February 1983 and the total removal of capital movement controls for non-residents (Tembo, 1999). As a result, a unified floating exchange rate (a commercial rand determined by the market) was adopted in August 1983, but it was subject to SARB intervention. This unified exchange rate stayed stable for a few months and then started to depreciate because of the 
decrease in gold price in 1983, the debt crisis and increasing political insecurity in 1984 (Takaendesa, 2006). In addition to this, financial sanctions were imposed on South Africa by global organisations in 1985 and the unified exchange rate dropped even further (Aron \& Muellbauer, 2001). To respond to this situation, a dual exchange rate system was reintroduced in September 1985 and this system continued until March 1995, when the exchange rate was reunified again.

In March 1995 the financial Rand was abolished and there was further relaxation of exchange rate and capital controls. This low level of control on the exchange rate marked the beginning a free-floating exchange rate system, through which the exchange rate was determined by market factors (Schaling, 2009). The adoption of the free floating exchange rate system exposed the rand to both domestic and external shocks, such as the Asian crisis, the decrease in the gold price in 1997, the September 2001 attack on America and the volatile political situation in Zimbabwe (Takaendesa, 2006). Although a free-floating exchange rate has been maintained (since 1995), there had been concerns over the intervention of the SARB to indirectly influence the value of the rand (Aron \& Muellbauer, 2001). In summary the period 1978-2008, had been characterised by two major exchange rate regimes, namely, managed floating (1978-1995) and fixed floating exchange rate (1995-2008).

\section{Methodology}

\subsection{Data}

The data set used in this study consists of monthly observations of the JSE All Share Index (JSE ALSI) and the monthly South African rand (ZAR) to U.S. dollar (USD) exchange rate series. The ZAR/USD exchange rate series were provided by the SARB. The historical stock market indices were obtained from the JSE (Johannesburg Stock Exchange, 2008). Both stock market indices and exchange rate series were adjusted for inflation to obtain real stock indices and real exchange rate series. Monthly inflation rates for South Africa were obtained from the Statistics South Africa (STATS SA, 2009), while monthly inflation rates for the USA were taken from the USA Bureau of Labor Statistics (2009). The sample period starts in January 1978 and ends in December 2008. The reason for starting the sample period in 1978 was to capture the introduction of some flexibility in the South African exchange rate market.

\subsection{Model}

In analysing the response of the JSE to different exchange rate regimes, this paper uses descriptive statistics such as means, standard deviations and Pearson correlation coefficients, while the Granger (1969) model is used to establish the causal relationship between the two variables during various exchange rate regimes.

\subsubsection{Unit Root Tests}

Before conducting the causality test, it is important to determine whether or not a series is stationary, as a non-stationary series can have a strong influence on its behaviour and properties. The use of non-stationary data can lead to spurious regressions, which yield un-interpretable results (Gujarati, 2003). Various ways of testing for stationarity include DickeyFuller (DF) unit root test, Augmented Dickey-Fuller (ADF) and the Phillips-Perron (PP) unit root tests (Brooks, 2008). These unit root tests (such as ADF and PP) tend to produce similar results, but they are criticised because they have low power and may lead to a poor decision in small sample sizes (Brooks, 2008; Gujarati, 2003). As a way of dealing with this problem of selecting the appropriate unit root test, the combination of stationarity (KPSS LM statistics ${ }^{1}$ ) and unit root test (DF, ADF and PP), known as confirmatory data analysis (Brooks, 2008) will be used in this paper. The equations for ADF and PP tests for the variables, based on a standard regression with a constant and time-trend (Abdalla \& Murinde, 1997), are as follows:

$$
\begin{aligned}
& \Delta X R_{t}=\alpha_{0}+\beta_{1} T+\lambda_{1} E R_{t-1}+\sum_{i=1}^{m} \alpha_{i} \Delta E R_{t-1}+\varepsilon_{1 t} \\
& \Delta S P_{t}=\alpha_{0}+\beta_{1} T+\lambda_{2} S P_{t-1}+\sum_{i=1}^{n} \delta_{i} \Delta S P_{t-1}+\varepsilon_{2 t}
\end{aligned}
$$

Where: $\Delta=$ the first difference operator: thus, $\Delta \mathrm{ERt}_{\mathrm{t}}=\mathrm{ER \textrm {t }}-\mathrm{ER \textrm {t } - 1}$ and $\Delta \mathrm{SPt}=\mathrm{SP} \mathrm{t}_{\mathrm{t}}-\mathrm{SP}_{\mathrm{t}-1} ; \mathrm{a}_{0}, \beta_{1}, \beta_{2}, \lambda_{1}, \lambda_{2}$, $\mathrm{a}_{\mathrm{i}}$, and $\delta$ i are the coefficients; $T$ is the time trend; and, $\varepsilon_{1}$ and, $\varepsilon_{2}$ are white noise error terms. The hypothesis tests for unit root (DF, ADF and PP) are:

1 For a detailed discussion of the KPSS test, see Kwiatkowski, Philips, Schmidt \& Shin (1992). 
$\mathrm{H}_{0}: \lambda_{1}=\lambda_{2}=1$ then $E R_{t}$ and $\mathrm{SP}_{\mathrm{t}}$ have a unit root, and

$\mathrm{H}_{1}: \lambda_{1}$ and $\lambda 2<1$ then $\mathrm{ER}_{\mathrm{t}}$ and $\mathrm{SP}_{\mathrm{t}}$ are stationary.

If these tests show that variables are non-stationary, then the first differencing will used to make them stationary (Gujarati, 2003). Once the variables are found to be stationary or have been transformed through differencing, Granger causality tests will be conducted.

\subsubsection{Granger Causality test}

Following (Abdalla \& Murinde, 1997), the Granger-Causality test for this study is as follows:

$$
\begin{aligned}
& X R_{t}=\sum_{j=1}^{m} \alpha_{j} X R_{t-j}+\sum_{j=1}^{n} \beta_{j} S P_{t-j}+e_{t} \\
& S P_{t}=\sum_{j=1}^{m} \gamma_{j} X R_{t-j}+\sum_{j=1}^{n} \delta_{j} S P_{t-j}+u_{t}
\end{aligned}
$$

Where: $\mathrm{XR} t$ is the real exchange rate variable, $\mathrm{SP}_{\mathrm{t}}$ is the real stock price variable, and $\mathrm{e}_{\mathrm{t}}$ and $\mathrm{u}_{\mathrm{t}}$ are error terms.

If the errors et and $u_{t}$ are contemporaneously correlated, a shock to one of the equations would have a ripple effect on the other equation (Patterson, 2000). Hence, each equation is assumed to have serially independent residuals, with zero mean and constant variance. In other words, both equations are assumed to be serially independent, with zero mean and a finite covariance matrix. If Equations 3 and 4 meet these assumptions then the causality analysis would be based on the following hypothesis tests:

Causality from the stock market to the exchange rate (Equation3):

$\mathrm{H}_{0}: \sum \beta_{j}=0, \mathrm{SP}_{\mathrm{t}}$ does not cause $\mathrm{XR}_{\mathrm{t}}$ and $\mathrm{H}_{\mathrm{t}}: \sum \beta_{j} \neq 0, \mathrm{SP}_{\mathrm{t}}$ cause $\mathrm{XR}_{\mathrm{t}}$

Causality the exchange rate to from the stock market (Equation4):

$\mathrm{H}_{0}: \sum \gamma_{j}=0, \mathrm{XR}_{\mathrm{t}}$ does not cause $\mathrm{SP}_{\mathrm{t}}$ and $\mathrm{H}_{1}: \sum \gamma_{j} \neq 0, \mathrm{XR}_{\mathrm{t}}$ cause $\mathrm{SP}_{\mathrm{t}}$.

These hypotheses indicate that there can be four possible outcomes from a causality test- one-way causation from real stock prices to the real exchange rate; one-way causation from the real exchange rate to the real stock price; mutual causation and no causal relationship between the real exchange rate and the real stock market index.

\section{Results and Discussion}

\subsection{Graphical analysis and descriptive statistics}

Section 2 showed that the South African economy has been characterised by different exchange rate policies. Two major periods characterised by different exchange rate regimes were identified. These two periods are the period of managed floating exchange rate regimes (1978-1995) and the period of free floating exchange rate regimes (1995-2008). First, descriptive statistics and graphical analysis are used to assess the relationship between the JSE and exchange rate fluctuations during these two sub-periods.

\subsubsection{The JSE and the Managed Floating Exchange Rate Regime}

The period of managed floating exchange rate regimes (January 1979 to March 1995) was divided into three subperiods, based on changes of exchange regimes. The first sub-period of a dual floating exchange rate regime runs from January 1979 to February 1983. The second sub-period, characterised by a unified floating exchange rate, runs from March 1983 to September 1985. The last sub-period started with the reintroduction of the dual floating exchange rate regime in October 1985 and ended in February 1995. The response of the JSE to these different regimes is conducted though a graphical analysis ${ }^{2}$ and descriptive statistics reported in Table 1.

A weak relationship between the JSE and the exchange rate was observed during the period of a dual managed floating exchange rate regime (January 1979 to February 1983). The JSE tended to fluctuate more than the nominal exchange rate. This may be a result of government intervention (in the foreign exchange market) that minimised fluctuations in the exchange rate. During this period of dual managed floating exchange rate regime, the JSE ALSI increased by $2.3 \%$, on average, while the exchange rate depreciated by $0.49 \%$. The coefficient of correlation between the two variables is -0.3480 and it is significant at the $5 \%$ level of significance (P-value $<5 \%$ ). Thus there is statistical

${ }^{2}$ Graphs are not included in this paper. They may be requested from to the author. 
evidence supporting a negative correlation between the two variables during this sub-period. This means that the depreciation of the exchange rate was accompanied by a decrease in the JSE ALSI.

Table 1: Descriptive Statistics (Managed Floating ER Regimes)

\begin{tabular}{|c|c|c|c|c|c|c|}
\hline ER policy & \multicolumn{2}{|c|}{$\begin{array}{l}\text { Dual floating } \\
\text { (Jan 79-Feb 83) }\end{array}$} & \multicolumn{2}{|c|}{$\begin{array}{l}\text { Unified floating } \\
\text { (Mar 83-Sept 85) }\end{array}$} & \multicolumn{2}{|c|}{$\begin{array}{l}\text { Dual floating } \\
\text { (Oct 85-Feb 95) }\end{array}$} \\
\hline Variable & JSE & ER & JSE & ER & JSE & ER \\
\hline Mean & $2.30 \%$ & $0.49 \%$ & $1.34 \%$ & $2.82 \%$ & $1.49 \%$ & $0.37 \%$ \\
\hline Standard Deviation & 0.0823 & 0.0205 & 0.0563 & 0.0556 & 0.0599 & 0.0320 \\
\hline Pearson correlation & -0.3480 & & -0.0418 & & 0.0952 & \\
\hline P-values (by SPSS) & $(0.013)$ & & $(0.822)$ & & $(0.316)$ & \\
\hline
\end{tabular}

Between March 1983 and September 1985, the dual exchange rate was replaced by a unified exchange rate. In 1983, small changes in the exchange rate were accompanied by major changes in the JSE ALSI, but in the opposite direction. In October 1983 for example, the exchange rate depreciated by $0.93 \%$, while the JSE ALSI decreased by $11.19 \%$. The magnitude of fluctuations increased during 1984 and 1985 because of credit crises. In July 1984, the JSE ALSI decreased by $10.17 \%$, while the exchange rate depreciated by $14.35 \%$. The highest change in the exchange rate for the whole period was a depreciation of $20.26 \%$ in August 1985 , while the highest change in the JSE ALSI was a decrease of $11.19 \%$ in October 1983. On average, the exchange rate depreciated by $2.82 \%$ during this period, while the JSE increased by $1.34 \%$. Correlation coefficient $(-0.042)$ between these two variables is still negative, but it is not statistically significant even at the $10 \%$ level of significance.

In October 1985 South Africa reintroduced a dual exchange rate. This second period of dual exchange was associated with increase in fluctuation of both variables, especially between 1985 and 1987. The highest change in the exchange rate was a depreciation of $15.53 \%$ in June 1986, while the highest change in JSE was a decrease of $23.76 \%$ in October 1987. On average, the exchange rate depreciated by $0.37 \%$ while the JSE increased by $1.49 \%$. The correlation coefficient of 0.095 shows a weak positive relationship between these two variables during this period. However, a P-value of 0.316 shows that this correlation is statistically insignificant.

Generally, the exchange rate depreciation was associated with a decrease in the JSE ALSI, while the exchange rate appreciation was associated with an increase in the JSE ALSI. The relationship between the JSE and the exchange rate tended to be strong in the first period of the dual exchange rate system. This means that the dual exchange rate system increased inflow of foreign investment to the JSE as this exchange rate regime encouraged foreign investors to keep assets in South Africa (Schaling, 2009). Under a unified exchange rate system, exchange rate fluctuations increased, while fluctuations in the JSE ALSI decreased. This may be linked to the total removal of capital movement controls for foreigners (Tembo, 1999), political insecurity and financial sanctions imposed on South Africa that caused the unified exchange rate to drop (Takaendesa, 2006). Under the flexible exchange rate system, the response of the JSE to currency fluctuations is not constant. It appears to be changing with changes in exchange rate regimes.

\subsubsection{The JSE and the Free Floating Exchange Rate Regime}

The period of free floating exchange rate (March 1995-December 2008) was divided into three sub-periods, based on the level of intervention of the SARB in the currency market and other regulations that limited the flexibility of the exchange rate market. A summary of descriptive statistics, for these there sub-periods, is in Table 2.The first period of the free floating exchange rate (March 1995 to June 1997) marked the establishment of a relatively competitive foreign exchange market in South Africa (SARB, 2010), but there was still some level of government intervention. This period was characterised by a great magnitude of changes in both variables, especially in 1996, when the JSE increased by $10.32 \%$ in January and the exchange rate depreciated by $7.06 \%$ in April. Average changes for the whole period show an increase of $1.36 \%$ in the JSE ALSI and an exchange rate depreciation of $0.86 \%$. The standard deviations for this period are 0.032 and 0.021 for the JSE ALSI and the exchange rate, respectively. This means that fluctuations in the JSE ALSI were slightly higher than the exchange rate fluctuations. The correlation coefficient $(-0.313)$ confirms a negative relationship. The P-value of 0.105 is close to the $10 \%$ level of significance and this suggests that the adoption of a free floating exchange rate regime increased the exposure of the JSE to exchange rate fluctuations. 
Table 2: Descriptive Statistics (Free Float ER Regimes)

\begin{tabular}{lllllll}
\hline \multirow{2}{*}{ ER Policy } & \multicolumn{2}{l}{$\begin{array}{l}\text { Free floating } \\
\text { (Marc 95-Jun97) }\end{array}$} & \multicolumn{2}{l}{$\begin{array}{l}\text { Free floating } \\
\text { (Jul 97-Feb 00) }\end{array}$} & \multicolumn{2}{l}{$\begin{array}{l}\text { Free floating } \\
\text { (Marc 00-Dec 08) }\end{array}$} \\
\hline Variable & JSE & ER & JSE & ER & JSE & ER \\
\hline Mean & $1.36 \%$ & $0.86 \%$ & $0.62 \%$ & $1.12 \%$ & $1.09 \%$ & $0.53 \%$ \\
Standard Deviation & 0.0315 & 0.0210 & 0.0853 & 0.0345 & 0.0553 & 0.0450 \\
Pearson correlation & -0.3130 & & -0.1892 & & -0.0552 & \\
P-value (by SPSS) & $(0,105)$ & & $(0.30)$ & & $(0.574)$ & \\
\hline
\end{tabular}

The second period of the free floating exchange rate (July 1997 to February 2000) was characterised by a considerable relaxation of exchange controls. During this period an increase in volatility in both markets was observed. The value of the rand fell significantly, with a depreciation of about $16.5 \%$ in July 1998, followed by a major decline in the JSE ALSI of about 30\%. These major declines in both markets may be explained by the Asian financial crisis and the decrease in the price of precious metals that affected the world during this period (Takaendesa, 2006). The average change in the exchange rate was $1.12 \%$ per period, while the average movement in the JSE was $0.062 \%$ per period. Standard deviations of 0.0853 and 0.0345 for the JSE and the exchange rate, respectively, show that the JSE experienced higher volatility. The common trend during this period is that changes in the exchange rate tended to be followed by changes of high magnitude in the JSE. Thus the relaxation of exchange control promoted high financial integration and increased the link between the JSE and the exchange rate. The Pearson coefficient of correlation is statistically insignificant meaning that there is no evidence of a strong correlation between the two variables during this sub-period.

The final period (March 2000 to December 2008) was a period of free floating exchange rate, with a high level of flexibility, without any direct intervention of government in the exchange rate market. This period was characterised by high levels of volatility in both markets and this volatility tended to be in both directions. However, the coefficient of correlation between the two variables $(-0.0552)$ is very low and statistically insignificant.

The period of free floating increased the exposure of the JSE to currency fluctuations, especially in the last subperiod, where movements of high magnitude are observed. All standard deviations tended to be high for the JSE, indicating that the stock market fluctuated more than the exchange rate market. The negative correlation coefficients for all three sub-periods supported the inverse relationship between the variables, but these correlations were not statistically significant. However, the first sub-period of free floating exchange rate tended to be significant at the 10\% level of significance. This supports the idea that the end of sanctions in 1994 and the abolition of the dual exchange rate in March 1995 led to the increased foreign investment portfolio in the JSE (Jefferis \& Okeahalam (2000). The analysis conducted on the sub-periods from both managed floating and free floating exchange rate regimes (separately) revealed that there may be a relationship between the JSE and the exchange rate under both regimes.

\subsection{Granger causality}

Before conducting a test for causality, ADF, PP and KPSS tests were used to test for unit root and stationarity in the variables. The results of these tests, with a trend and intercept, are reported in Table 3.

Table 3: Unit Roots and Stationarity Tests

\begin{tabular}{|c|c|c|c|c|c|c|c|}
\hline & Level & & First Dif & ice & Test & al Value & \\
\hline & SP & ER & $\Delta \mathrm{SP}$ & $\Delta \mathrm{ER}$ & $1 \%$ & $5 \%$ & $10 \%$ \\
\hline ADF & -3.069 & -2.114 & -17.511 & -14.507 & -3.983 & -3.422 & -3.134 \\
\hline PP & -3.220 & -1.955 & 17.502 & -14.418 & -3.983 & -3.422 & -3.134 \\
\hline KPSS & 0.3098 & 0.2643 & 0.0325 & 0.0594 & 0.216 & 0.146 & 0.119 \\
\hline
\end{tabular}

The ADF and PP fails to reject the null hypothesis (for both variables) at the $5 \%$ level of significance indicating that that both variables have a unit root. Under the KPSS test, the null hypothesis was rejected, for both variables, because the LM-statistics are greater than all critical values. This indicates that the series are not stationary in their level and this

${ }^{3}$ Critical values based on MacKinnon (1996) and KPSS (1992) are shown in the last three columns and the lag order for the series was determined by the Schwarz information criterion, automatically set by Eviews software. 
means that the first differences should be used. For the first difference, the ADF and PP test statistics are more negative than critical values at all levels of significance. This means that there is no unit root in first difference of the variables. The LM-statistics for the KPSS test are smaller than critical values at all levels of significance; this confirms the ADF and PP conclusion that both variables are stationary in their first differences. In testing for causality, variables are therefore firstdifferenced.

Granger causality test for managed floating exchange rate regimes, in Table 4, show that there was a causal relationship from the stock market to the exchange rate during the first sub-period of dual exchange rate (Jan 1979February 1983). However, the causal link between the stock market and the exchange rate was statistically insignificant during the unified floating and the second sub-period of dual floating exchange rate.

Table 4: Granger causality for managed floating exchange rate regimes

\begin{tabular}{|c|c|c|c|c|c|c|}
\hline & \multicolumn{2}{|c|}{$\begin{array}{l}\text { Dual floating } \\
\text { (Jan 79-Feb 83) }\end{array}$} & \multicolumn{2}{|c|}{$\begin{array}{l}\text { Unified floating } \\
\text { (Mar 83-Sept } 85\end{array}$} & \multicolumn{2}{|c|}{$\begin{array}{l}\text { Dual floating } \\
\text { (Oct 85-Feb 95) }\end{array}$} \\
\hline Null Hypothesis: & F-Statistic & Prob. & F-Statistic & Prob. & F-Statistic & Prob. \\
\hline $\begin{array}{l}\triangle \mathrm{SP} \text { does not Granger } \\
\text { Cause } \Delta \mathrm{ER}\end{array}$ & $3.2697^{\star *}$ & 0.046 & 0.5590 & 0.579 & 0.3678 & 0.693 \\
\hline $\begin{array}{l}\Delta \mathrm{ER} \text { does not Granger } \\
\text { Cause } \Delta S P\end{array}$ & 0.466 & 0.630 & 0.4102 & 0.668 & 1.0516 & 0.353 \\
\hline
\end{tabular}

** Significant at $5 \%$ level of significance, * significant at $10 \%$ level of significance

Table 5 shows that there was a causal link from the exchange rate to stock market during last two sub-periods of the free floating exchange rate. It is important to note that during the period of managed floating exchange rate, the direction of causality was from the stock market to the exchange rate, while during the period of free floating exchange rate, this direction moved from the exchange rate to the stock market.

Table 5: Granger causality for Free Float Exchange Rate Regimes

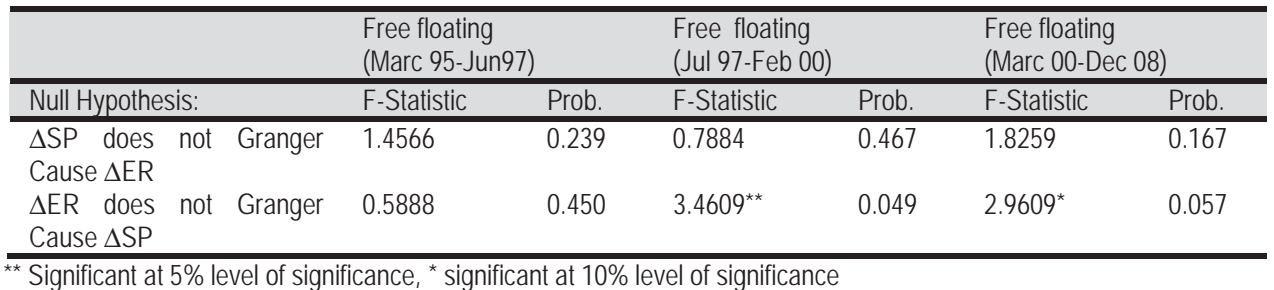

In general, a negative relationship between the JSE and the exchange has been found. This implies that the depreciation of the rand was associated with a decrease in the share price of the JSE ALSI. These findings are similar to those of Barr \& Kantor (2005) who found negative relationship between the JSE and the exchange rate from 1980 to 2002 and Jefferis \& Okeahalam (2000) who concluded that the JSE's returns increased with the appreciation of the rand and decreased with the depreciation of the rand. Since Pearson coefficients were only significant the sub-periods characterised by capital controls, this suggests that capital control have a significant impact the exchange rate. Granger causality revealed that changes in the exchange rate regimes led to changes in the direction of the causality between the JSE and the exchange rate.

\section{Conclusion}

The overview of the exchange rate in South Africa revealed that South Africa has been characterised by different exchange rate regimes, but these regimes can be condensed into two categories- fixed and free-floating exchange rate regimes. The analysis of the history of the exchange rate in South Africa showed that the flexibility was introduced in 1979 but the exchange rate shocks of great magnitude appeared during the period of the free-floating exchange rate regime (1995-2008). The relationship between the JSE and the exchange rate increased during the period of the free floating exchange rate; meaning that the exposure of the JSE to currency risks increased during this period (1995-2008). 
In all exchange rate regimes, the JSE's return decreased with the depreciation of the rand and increased with the appreciation of the Rand. This study found that the JSE ALSI responded to changes in exchange rate regimes, but the response was not consistent during these different exchange rate regimes. Although the response was slightly stronger during the period of the free floating exchange rate, Pearson coefficients were only significant in the sub-periods characterised by capital controls. To add to this, Granger causality test revealed that changes in the exchange rate regimes led to changes in the direction of the causality between the two variables. These findings suggest that capital control and changes in exchange rate regimes have a significant impact on the relationship between the exchange rate and the stock market. Policymakers should therefore consider this implication of exchange rate policies on the stock market. Future researchers may use the GARCH model to determine whetheror not changes in regimes exchange rate regimes have an impact on the stock market volatility.

\section{References}

Abdalla, I., \& Murinde, V. (1997). Exchange rate and stock price interactions in emerging financial markets: evidence on India, Korea, Pakistan and the Philippines. Applied Financial Economics, 7, 25- 35.

Ajayi, R., Friedman, J., \& Mehdian, S. (1998). On the Relationship between Stock Returns and Exchange Rates: Test of Granger Causality. Global Finance Journal, 9(2), 241-251.

Aron, J., \& Muellbauer, J. (2001). Interest rate effects on output: evidence from a GDP forecasting model for South Africa. 2nd Annual Research Conference. International Monetary Fund.

Benson, K. L., \& Faff, R. W. (2003). Exchange Rate Sensitivity of Australian International Equity Funds. Global Finance Journal, 14(1), 95-120.

Brooks, C. (2008). Introductory Econometrics for Finance (2nd ed.). UK: Cambridge University Press.

Fischer, S. (2001). Distinguished Lecture on Economics in Government Exchange Rate Regimes: is the Bipolar View Correct? Journal of Economic Perspectives, 15(2), 3-24.

Granger, C. J., Huang, B., \& Yang, C. (2000). A Bivariate Causality between Stock Prices and Exchange Rates: Evidence from Recent Asian Flu. Quarterly Review of Economics and Finance, 40(3), 337-54.

Gujarati, N. (2003). Basic Economtrics (4th ed.). New York: McGraw-Hill.

Johannesburg Stock Exchange. (2008). Financial Statements and JSE All Share Index. [Online] Available: http://wwww.ise.co.za (April 10, 2009).

Klein, M., \& Shambaugh, J. (2008). The Dynamics of Exchange Rate Regimes: Fixes, Floats, and Flips. Journal of International Economics, 75, 70-92.

Kwiatkowski, D., Philips, P. B., Schmidt, P., \& Shin, Y. (1992). Testing the Null Hypothesis of Stationary Against the Alternative of a Unit Root. Journal of Econometrics, 54, 159-178.

Madura, J. (2003). International Financial Management (7th ed ed.). USA: Thomson.

Patterson, K. (2000). An Introduction to Applied Econometrics: A Time Series Approach. (2nd ed.). London: MacMillan Press Ltd.

Reinhart, C. (2000). The Mirage of Floating Exchange Rates. The American Economic Review, 90(2), 65-70.

Schaling, E. (2009). Capital Controls, Two-Tiered Exchange Rate System and Exchange Rate Policy:. South African Journal of Economics, 77 (4), 505-530.

Schindler, M. (2009). Measuring Financial Integration: A New Data Set. IMF Staff Papers, 56(1), 222-238.

South African Reserve Bank. (2010). Statistical information: Selected Historical Exchange Rates and Other Interest Rates. [Online] Available: http://www.reservebank.co.za (February 15, 2011).

STATS SA. (2009). Key Economic Indicators. [Online] Available: http://www.statssa.gov.za/keyindicators/cpi.asp (January 12, 2010)

Takaendesa, P. (2006). The Behaviour and Fundamental Determinants of the Real Exchange Rate in South Africa. Master Dissertation: Rhodes University.

Tembo, G. (1999). An Analysis of Real Exchange Rate Disequilibrium in Developing Countries, with an Empirical focus on South Africa. Master of Social Science Dissertation. . Pietermaritzburg: University of Natal.

The Bureau of Labor Statistics . (2009). Historical US Inflation Rate 1914-Present.[Online] Available: www.inflationdata.com (January 07, 2010).

Van der Merwe, E. J. (2003). Exchange rate Regime and Monetary Arrangement in South Africa. [Online] Available: http://www.docstoc.com (April 02, 2010). 